\title{
Aeneas the flamen: double togas and taboos in Virgil's Carthage ${ }^{1}$
}

\section{I}

This is an investigation of an aspect of Virgil's Aeneid - ultimately, of the ways in which the poet guides his reader's response to Aeneas' stay in Carthage - and while it touches on Roman religious practice, clothing codes, late-antique Virgilian commentary and Augustan ideology, it hinges on a single word in Aeneid 4 and its implications for Virgil's depiction of his hero in this book. That word is laena, and it features in one of the most celebrated scenes of the poem, when Mercury descends to earth to find Aeneas busily engaged in founding Carthage:
ut primum alatis tetigit magalia plantis,
Aenean fundantem arces ac tecta nouantem
conspicit. atque illi stellatus iaspide fulua
ensis erat Tyrioque ardebat murice laena
demissa ex umeris, diues quae munera Dido
fecerat, et tenui telas discreuerat auro.

Aen. 4.259-264

\begin{abstract}
As soon as Mercury with winged feet touched the Carthaginian huts, he caught sight of Aeneas founding the citadel and raising new buildings: his sword was studded with stars of yellow jasper, and a laena, hanging from/let down from ${ }^{2}$ his shoulders, blazed with Tyrian purple, a gift that Dido with her wealth had made, interweaving in the web a subtle crossthread of gold.
\end{abstract}

\footnotetext{
${ }^{1}$ My thanks are due to Nicholas Purcell, a comment from whom after a talk about Aen. 4.462-3 set the mental dominoes toppling; to Josephine Quinn for fascinating bibliography on tophet; and to Roberta Stewart, who generously shared her immense expertise on the early first century BC. A number of anonymous readers have seen and commented on this article in its extended gestation, and I am grateful to all of them.

2 The implications of demissa ex umeris, and the possible interpretations of the expression, are discussed at pp. 00 below.
} 
4.262 is the only place in the Aeneid where this word is used, ${ }^{3}$ and I shall be suggesting that the laena represents an unusually evocative piece of clothing to put on Aeneas, even aside from the particular character, its decoration and origin, that Virgil attributes to the example Aeneas is wearing at 262-4. What I offer is a cumulative argument, as a whole (I believe) persuasive but also necessarily speculative given the limited state of our knowledge in various areas from religion to clothing. My essential claim is that Virgil is encouraging his reader at this point in the poem to associate Aeneas with, and judge his behaviour in comparison to, one of the most important members of the Roman priesthood.

The passage in which this description of Aeneas and his clothing falls is a densely written piece of narrative. The context is highly embellished, in particular through the involvement of Jupiter and Mercury, the latter's flight elaborately prepared for and flamboyant in itself, and enforced by Homeric, Apollonian and indeed Virgilian precedents. ${ }^{4}$ This intensification alone marks it as an episode of unusual significance: it is, as Feeney suggests, a sequence of narrative events so challenging that as we read it we share something of what Aeneas experiences, surprised and disorientated by this god who appears out of the blue. $^{5}$ Symbolic intensification accompanies narrative. Hardie has drawn out the philosophical associations activated by Atlas and Mercury, Atlas a figure for Stoic apatheia, ${ }^{6}$ Mercury for the workings of $\lambda$ ó $\gamma$ os or ratio: ${ }^{7}$ we have an allegory of Aeneas coming to his senses, in other words, quite literally seeing reason. ${ }^{8}$ As Gordon has helped us appreciate, it

\footnotetext{
3 J. J. O'Hara, Vergil, Aeneid 4 (Newburyport, 2011), ad loc.

${ }^{4}$ Hom. Od. 5.43-148, with G. N. Knauer, Die Aeneis und Homer (Göttingen, 1964), 209-14; Ap. Arg. esp. 3.156-7 and 4.757-69 with D. Nelis, Vergil's Aeneid and the Argonautica of Apollonius Rhodius (Leeds, 2001), 155-9; Aen.1.297-304, and see also P. R. Hardie, Virgil's Aeneid: Cosmos and Imperium (Oxford, 1986), 276-9 for the points of contact and contrast between Mercury and Virgil's earlier depiction of Fama. D. C. Feeney, 'Leaving Dido: the appearance(s) of Mercury and the motivations of Aeneas', in M. Burden (ed.), A woman scorn'd: responses to the Dido myth (London, 1998), 105-27 discusses the interventions of Virgil's Mercury in relation to each other and Virgil's models in Homer and Apollonius.

${ }^{5}$ See especially D. C. Feeney, The Gods in Epic (Oxford, 1991), 173-5.

${ }^{6}$ Hardie (n. 4), 373-5.

${ }^{7}$ Hardie (n. 4), 278-9.

${ }^{8}$ Feeney (n. 4), 112 draws out Mercury's related role as the 'adversary of forgetfulness'.
} 
is to an important extent from the Epicurean perspective intermittently associated with Dido and Carthage that Aeneas is being rescued here, and it is of course apt that this conversion is achieved by so overt an intervention of the divine in human affairs, the reality of which Dido proceeds to dispute in 'crypto-Epicurean' terms (4.376-80). ${ }^{9}$ All of this conspires to mark this as a critical point in the plot, and appropriately so: Aeneas is encountered at his most settled in Carthage, actively engaged in the ongoing foundation of Dido's new city; what ensues is a traumatic correction that will restore him as Rome's ancestral hero. The moment on which I am focusing in this article captures Aeneas in the midst of this narrative tour-de-force, just in advance of his dramatic self-realisation.

The laena that Aeneas is wearing when Mercury confronts him is a traditional Roman garment, and we have reasonably detailed information about it, both what it looked like and what it connoted. The latter is an important consideration given 'the role that correct, traditional dress played in Roman civic ideology, and especially the continued centrality of the toga and stola to the very definition of what it meant to be Roman.' ${ }^{10}$ In other words, there was a strong 'semiotics of dress' at Rome: the formal toga, for example, when worn, not worn, inappropriately worn or worn by inappropriate people, could communicate important information about moral behaviour (Cic. Cat. 2.22; Suet. Tib. 13.1), social difference (Polyb. 6.53.7; Tac. Dial. 7.4), the division between otium and negotium (Plin. Ep. 5.6.45; Martial 1.49.31-2) and between war and peace (Cic. Pis. 73 with De Orat. 3.27), and ultimately Roman identity itself (Hor. Carm. 3.5.10; Sen. Apoc. 3.3; Suet. Aug. 40.5, 44.2;

\footnotetext{
9 P. Gordon, 'Phaeacian Dido: Lost Pleasures of an Epicurean Intertext', Classical Antiquity 17 (1998), 188-211, with a quotation from 203. Cf. J. T. Dyson, 'Dido the Epicurean', Classical Antiquity 15 (1996), 203-221.

$10 \mathrm{~J}$. Edmondson, 'Public dress and social control in Late Republican and Early Imperial Rome,' in J. Edmondson and A. Keith, Roman dress and the fabrics of Roman culture (Toronto, 2009), 21-46, at 34.
} 
Claud. 15.2; Plin. Ep. 4.11.3). ${ }^{11}$ That awareness of the significance of clothing is of course abundantly illustrated in the Aeneid itself (1.282, cited by Augustus; Aen. 9.614-16, with Aul. Gell. NA 6.12). ${ }^{12}$

The laena is a close relation of the toga, we are informed, but possessed of an even more formal character than the habitus patrius et ciuilis, 'the national gear of the citizen' (Suet. Calig. 52.1). Varro (Ling. 5.133) provides an etymology, and identifies it as an unusually ancient (and it follows, especially formal) item of clothing, a kind of elaboration of the simple toga: laena, quod de lana multa, duarum etiam togarum instar; ut antiquissimum mulierum ricinium, sic hoc duplex uirorum, 'The laena is so called because it is woven from much wool, equivalent in fact to two togas: as the ricinium is the most ancient garment for women, so this double toga is for men' (Varro Ling. 5.133). As Varro informs us, the laena was in fact 'a double toga', 'equivalent to two togas':13 depictions of it, on the south frieze of the Ara Pacis, for example, ${ }^{14}$ or on a statue from Mérida in Spain, ${ }^{15}$ show a bulky woollen garment covering both shoulders (the toga, also made of wool, typically covered just the left). ${ }^{16}$

But further testimonia about the laena indicate a more specific association. This most venerable of male garments was closely identified with a priesthood of commensurate antiquity, the flaminate (in Latin flamonium or flaminatus). ${ }^{17}$ A note by Servius on this very passage in Aeneid 4 calls it a togaduplex in qua flamines sacrificant infibulati, 'a double toga

\footnotetext{
${ }^{11}$ Edmondson (n.9).

12 P. R. Hardie, Virgil, Aeneid Book IX (Cambridge, 1994), at 616 relates Numanus Remulus' account of Trojan dress to the locus classicus for Roman clothing codes, Cic. Cat. 2.22. See also Hardie at 614 for further examples of meaningful clothing sported by characters in the poem.

${ }^{13}$ Edmondson and Keith (n. 10), 13, 29.

${ }^{14}$ P. Zanker, The power of images in the age of Augustus (Ann Arbor, 1988), 120 fig. 98.

15 Edmonds on and Keith (n. 10), fig. 1.5.

16 The ricinium mentioned by Varro as a comparably ancient item of clothing was a fringed shawl associated with widows, and thus again of high formality: see L. Sensi, 'Ornatus e status sociale delle donne romane', APer $18(1980 / 81), 53-102$, at 65.

${ }^{17} R E$ 6.2485.9-14.
} 
in which the flamines, pinned-up, perform sacrifice' (Serv. Auct. at Aen. 4.262), and his source is Suetonius (Gloss. Vat. s.v. 'Laena' = Suet. fr. 167 Reifferscheid, from De genere uestium): LAENA amictus rotundus duplex, ut ait Iulius †Suauis. Suetonius uero ait: toga duplex, qua infibulati flamines sacrificant. huius uestis inuentor Laenas appellatus est, 'The laena is a circular, double garment, as Iulius Suavis says. Suetonius says: "A double toga pinned up in which the flamines perform sacrifice." The description of the laena as an amictus rotundus would seem consonant with Dionysius of Halicarnassus' reference to the simple toga as, at rest, semicircular (Ant. Rom. 3.61.1, but cf. Quint. Inst. 11.3.139: there is much that remains mysterious about the precise form of the laena), while the intriguing detail about pins relates to strict taboos that governed the behaviour, including the dress, of these priests, but especially the chief flamen known as the flamen Dialis. These made this priest an object of interest for ancient antiquarians, and we are the beneficiaries of that interest, as we shall see. In this instance the explanation of the fibulae which were such a noticeable aspect of the flamen's appearance is that any kind of knot was prohibited to the flamen, and hence his bulky clothing apparently had to be held together by fibulae. ${ }^{18}$

From Brutus 56 comes an anecdote that Cicero uses to illustrate oratorical ability in early times (this story would date to the fourth century), but which is in origin clearly an aetiological tale explaining the cognomen of the Popillii Laenates (for a variation, see Suet. fr. 167 above), and which also conveys the authority embodied in the laena itself: 19

licet aliquid etiam de M. Popilli ingenio suspicari, qui cum consules set eodemque tempore sacrificium publicum cum laena faceret, quod erat flamen Carmentalis, plebei contra patres concitatione et seditione nuntiata, ut erat laena amictus ita uenit in contionem seditionemque cum auctoritate tum oratione sedauit.

\footnotetext{
${ }^{18}$ On fibulae see further n. 80 below.

${ }^{19}$ W. Nippel, Public order in ancient Rome (Cambridge, 1995), 32; Edmondson (n. 10), 29.
} 
We may also intimate something about Marcus Popilius' oratorical talent: when he was consuland was also performing a public sacrifice wearing a laena because he was the flamen of Carmentis, word was brought of a disturbance and rebellion of the people against the senate. Just as he was, clad in his laena, he headed to the public gathering and calmed them down both by his authority and his words.

The laena is not just a double-toga, in other words, but a super-toga, bringing with it the status represented by the toga but significantly amplified.

To turn back to Aeneas in Carthage momentarily, then, Virgil is specific about the garment he is wearing, using a marked term found on this single occasion in the entire poem. Furthermore the item of clothing in question turns out to possess particular prestige at Rome. Even if left there, Aeneas' sporting of the laena is arrestingly inappropriate given where he is and what he is doing: in Carthage, engaged in the founding of Carthage. Now, considerable scholarly attention has been given to the decoration and origin of Aeneas' clothing at this point. Lyne traces Mercury's offence at the sight of Aeneas partly to the 'obviously foreign' 'flashy and shameful cloak' he is wearing, a garment furthermore woven and given to him by the foreign queen, and Lyne also highlights the allusion to Antony's style of dress in Alexandria (Florus 2.21.3) and the Tyrian origin of its colouring (Tyrio ... murice, 262). ${ }^{20}$ Reed similarly interprets Aeneas' attire at $260-64$ as 'oriental', illustrating the degree to which the hero has reverted to the category of 'softened Easterner' that as a Trojan aspiring to Romanness he should be leaving behind. ${ }^{21}$ Lyne and Reed both also consider the return of garments made by Dido at $11.72-77$ (75 repeats 4.264$)$, at the very least a dark note attending the preparation of Pallas' body for cremation. ${ }^{22}$ Starks meanwhile identifies in Virgil's

\footnotetext{
${ }^{20}$ R. O. A. M. Lyne, Words and the poet: characteristic techniques of style in Vergil's Aeneid (Oxford, 1989), 188-9.

${ }^{21}$ J. D. Reed, Virgil's gaze: nation and poetry in the Aeneid (Princeton, 2007), 85-6, cf. 200.

22 Both scholars assume that of the two garments mentioned at 11.72, Aeneas only uses one to wrap Pallas' body, and thus has not only retained tokens of Dido and the 'orientalness' she brings with her even as far as this late stage of his mission to establish Rome, but will continue to do so. N. Horsfall, Virgil, Aeneid 11: a commentary (Leiden, 2003), suggests in a rich note at 72-7, with further bibliography, that 76-7 may be less definitive than that, indicating that one uestis is used for Pallas' body, and one for his head. In either case the poet returns us forcefully to a moment of intense crisis earlier in the poem.
} 
description an allusion to Plautus' Poenulus:.23 at 1296-1303 Antamonides indulges in 'some openly racist abuse'24 at the expense of the Carthaginian character Hanno, and at 1298 and 1303 Hanno's dress is pilloried as stereotypically Carthaginian, a tunic extended down to the hands or the ankles. ${ }^{25}$ These slovenly tunicae demissiciae (1303) of Antamonides'

Carthaginians, Starks proposes, anticipate Virgil's expression demissa ex umeris, suggesting that the 'lay' of Aeneas' clothing hints at a Punic character (how precisely to read these elusive words of Virgil we will consider at a later stage). With comparable implications, Weber compares Aeneas' appearance to a statue of Dionysus displayed by Ptolemy Philadelphus in a procession described by the historian Callixeinus (Athen. $198 \mathrm{c}=$ Callixeinus FGrH 627 fr. 2). ${ }^{26}$ What Antamonides in the Poenulus drew from Hanno's freeflowing clothing was that he, along with all his race, was mulierosus, excessively interested in women, and that might resonate with a detail of Servius' note at 263, DEMISSA EX UMERIS ex qualitate amictus ornatum amatoris expressit, 'By the character of the dress Virgil portrayed the costume of a lover. ${ }^{27}$ An amatory note is certainly introduced by another point of reference in Virgil's description of Aeneas, Jason in his elaborate cloak before his

\footnotetext{
23 J. H. Starks, Jr., 'The transference of Punic stereotypes in the Aeneid', The Classical Journal 94 (1999), 25583 , at 273-4 n. 43.

${ }^{24}$ G. F. Franko, 'The characterization of Hanno in Plautus' Poenulus', AJPh 117 (1996), 425-52, at 443.

${ }^{25}$ Cf. Enn. Ann. fr. 303 Sk. with O. Skutsch, The Annals of Quintus Ennius (Oxford, 1985), 480, citing (in addition to Plautus) Aul. Gell. NA 6.12 (who cites in turn both Enn. Ann. 303 Sk and Aen. 9.616), Cic. Cat. 2.22, Verr. 2.5.31, Hor. Serm. 1.2.25, Aug. De doctr. Christ.3.12.20. On Aen. 9.616 cf. Hardie (n. 12), ad loc.

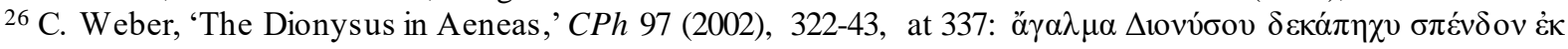

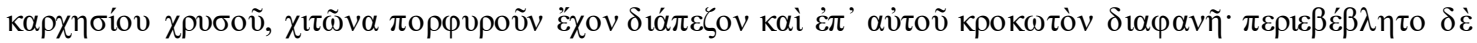

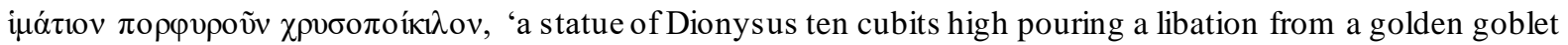
and wearing a purple tunic falling down to its feet and a diaphanous saffron robe over it. A purple cloak

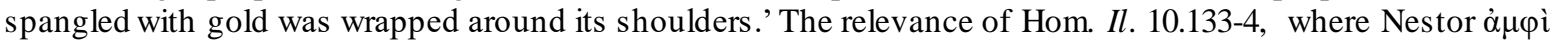

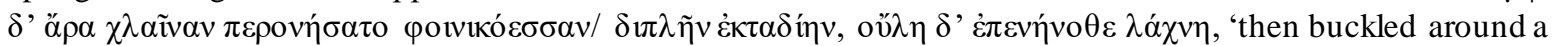
purple $\chi \lambda \alpha$ aiv $\alpha$, of double fold and broad, and the woolly nap was thick upon it' is less clear, but for the notion of an etymological connection between laena and $\chi \lambda \alpha \tilde{v} \alpha$, , seemingly a kind of cape (DNP s.v. chlaina), see Juba at Plut. Num. 7.5 (= GRF 453.5), and it presumably also lies behind Nonius Marcellus 541, citing this moment in the Aeneid, uestimentum militare quod supra omnia uestimenta sumitur, 'a military garment worn outside other clothes,' a better account of the $\chi \lambda \alpha \tilde{v} \alpha$ than the laena. For a brisk modern refutal of the etymological link, see $T L L$ s.v. laena, but we cannot rule out a false etymology influencing Roman application of the word.

${ }^{27}$ Cf. Serv. Auct. at 4.262, quidammuliebrem uestem quasi amatori aptamuolunt, 'Some take it as womanly clothing suitable for a lover.'
} 
meeting with Hypsipyle on Lemnos (Ap. Arg. 1.721-9 especially), a set piece that contributes to this among a number of passages in the Aeneid, as Nelis explains. ${ }^{28}$

It is noteworthy that in all these detailed and broadly consistent readings of Aeneas' clothing there is little said about the word laena itself, or the particular garment so denoted. Even O'Hara, who identifies it as 'a thick woollen cloak, worn by a flamen', draws no further conclusions. ${ }^{29}$ But if the consensus of the scholarship is that Aeneas' clothing is foreign, whether Punic or Greek, and suggestive of sexual deviancy, what is most striking about the term laena is that it bears the very opposite associations: it could not be more Roman, and furthermore (as we shall shortly see) evokes the very highest standards of sexual propriety. Virgil might at this moment of greatest assimilation have dressed his hero in a Carthaginian arm-length tunic. But he seems rather to have clothed him in an archetypally Roman garment, albeit garishly and decadently decorated, as he brings Rome's greatest enemy into existence.

Inseparable from the Romanness of the laena, however, is its status as the special garment of the flamen, and it is the possibility that the laena worn by Aeneas is a sufficiently exclusive marker to identify Aeneas as a flamen that is the main concern of this article. My case is based not only on this striking usage at 4.262 but also on what I shall suggest is an arresting sequence of parallels between the observable concerns of the flamen and the

\footnotetext{
${ }^{28}$ D. Nelis, Vergil's Aeneid and the Argonautica of Apollonius Rhodius (Leeds, 2001), 158. How unusual a laena thus adorned would seem of course depends somewhat on the standard appearance of the flamen's laena, and that is obscure. Marquardt's assumption at J. Marquardt and Th. Mommsen, Handbuch der römischen Altertümer $^{2}$ VI (J. Marquardt, Römische Staatsverwaltung III) (Leipzig, 1878), 317 is that the praetexta to which we hear that the flamen Dialis had a right (Livy 27.8.8; Servius at Aen. 8.552) was identical with the laena that he was obliged to wear at least at sacrifices and perhaps permanently. In that case the flaminal laena was white with a purple border, and Aeneas' laena a much more opulently coloured garment. Comparable, potentially, is the elaborate sword that Aeneas is carrying, since the secespita or sacrificial knife of the flamen was also elaborate (Servius at Aen. 4.262, repeating a description that Festus, Gloss. Lat. 4, 437 derives from M. Antistius Labeo, an Augustan-era jurist) but again less luxurious than Aeneas'weapon (for jasper, see Martial 9.59.20). 29 O’Hara (n. 3), at 262.
} 
particular circumstances of Aeneas in Aeneid 4, and finally on a peculiar preoccupation with the flaminate to be found in Servius' commentary on relevant parts of the Aeneid.

\section{III}

To Servius I shall come in good time, but I start with a rapid survey of this priesthood, drawing out its pertinence to Aeneas in Carthage. ${ }^{30}$

There were, historically, fifteen priests named flamines, three major and twelve minor (M. Popillius Laenas had been one of the latter, the flamen Carmentalis); the major flamines were the flamen Dialis, Martialis and Quirinalis, of Jupiter, Mars and Quirinus, to the relevant one of whom they made sacrifice. ${ }^{31}$ Of those three, the most senior, and the focus of by far the majority of ancient attention and commentary, was the flamen Dialis, the priest of Jupiter: maximae dignitatis Flamen Dialis est inter quindecim Flamines... minimi habetur Pomonalis, 'The Flamen of Jupiter has the highest status among the fifteen flamines ... the Flamen of Pomona the least,' Festus informs us (s.v. Maximae dignitatis, Gloss. Lat. Lindsay 4, 272). ${ }^{32}$ An indication of his seniority is that the word flamen, when used without qualification, denotes the flamen Dialis, and in what remains I shall regularly be adopting this ancient shorthand.

\footnotetext{
${ }^{30}$ Comprehensive descriptions of the priesthood may be found in $R E$ VI.2484-92 (E. Samter); C. Jullien, 'Flamen, flaminica, flamonia', in C. Daremberg and E. Saglio (eds.) Dictionnaire des antiquités grecques et romains: d'après les textes et les monuments (Paris, 1877-1919), 2.1156-88; J. H. Vanggaard, The flamen: a study in the history and sociology of Roman religion (Copenhagen, 1988); M. J. DiLuzio, A place at the altar: priestesses in republican Rome (Princeton, 2016), 17-51. There is a concise but helpful summary of the flaminate and the sources of our information on it in R. J. Starr, 'Aeneas as the Flamen Dialis? Vergil's Aeneid and the Servian exegetical tradition', Vergilius 43 (1997), 63-70, at 63-4. If the central thesis of G. Dumézil, Flamen-Brahman (Paris, 1935) is no longer credited, it offers nevertheless much interesting insight into this priesthood.

${ }^{31}$ Plin. HN 28.146 refers to the flamen Dialis as the flamen sacrorum.

32 Vanggaard (n. 30), 27.
} 
What drew ancient attention to the flamen Dialis more than anything else was the remarkable agglomeration of caerimoniae, 'ritual prohibitions', 'taboos', that regulated his existence. We have already encountered one related to the prohibition of knots in his clothing (nodum in apice neque in cinctu neque alia in parte ullum habet, 'He has no knot in his headwear, nor in the girding nor in any other part of his clothes,' Gellius 10.15.9; cf. Festus, Gloss. Lat. 4, 237 Lindsay), and this rule has been connected in ancient and modern discussion with other restrictions. He could not name ivy, for example (Gellius 10.15.12; Plut. QR 112; Festus, Gloss. Lat. 4, 198 Lindsay), walk under a vine arbour (Gellius 10.15.13; cf. Plut. $Q R$ 112), or have contact with any human bearing chains: if anyone in chains took refuge in the flamen's house, he was immediately relieved of them, and the shackles were then conveyed out into the street via the opening in the atrium roof (Gellius 10.15.8; Plut. $Q R$ 111; Servius at Aen. 2.76). Similarly the flamen's ring had to be split so that it could not fully encircle his finger (Gellius 10.15.6; Festus, Gloss. Lat. 4, 198 Lindsay), and he was not allowed to take, and thus be bound by, an oath (Gellius 10.15.5, 31; Plut. $Q R$ 44; Festus, Gloss. Lat. 4, 226 Lindsay).

The prohibition of knots illustrates how such limitations on the flamen Dialis' lifestyle only constitute restrictions from one perspective: from another, the priest is being systematically freed of any entanglement with the everyday world in order to ensure his proximity to the god that he serves. ${ }^{33}$ 'The flamen and flaminica [the flamen's wife and fellow priest], it seems, could be constrained only by the regulations associated with their priesthood. ${ }^{34}$ But if my ultimate contention is that there are meaningful points of resemblance between Aeneas' circumstances at Carthage and what ancient accounts tell us about the flamen, this inability to be constrained by an oath parallels in an intriguing way

\footnotetext{
33 Vanggaard (n. 30), 90.

${ }^{34}$ Diluzio (n. 30), 36.
} 
Aeneas' insistence to Dido that his relationship with her involved no foedus (Aen. 4.339; cf. 307).

An issue that takes us to the very heart of the flaminate, and also resonates powerfully with Aeneid 4, is marriage. The flaminate was felt to be exceedingly ancient, deriving ex horrida illa antiquitate, 'from those rough ancient times,' according to Tacitus' Tiberius (Ann. 4.16) and established by Numa-which is effectively to say, as old as Rome. ${ }^{35}$ It was in essence constituted not by the flamen alone but by the flaminal family, the flamen together with his wife the flaminica, ${ }^{36}$ and it seems to have represented for Romans an image of the ideal original household. ${ }^{37}$ A purported requirement that would reinforce this pristine character, and is inherently plausible, is Servius' comment (at Aen. 4.262, 263; 12.120, providing an authenticating anecdote) that the flamen's clothes must be made by his wife the flaminica: Servius records this detail against Virgil's careful indication that Aeneas' laena had been woven by Dido. ${ }^{38}$

Significant attention is also given in the sources to the details of the flamen and flaminica's marital arrangements. They, and their parents before them, were required to be married according to the ritual of confarreatio, the most solemn and (it was believed) ${ }^{39}$ most ancient (Dion. Hal. Rom. Ant. 2.25 for its antiquity) of the three early-Roman procedures for

\footnotetext{
35 Varro LL 7.45; Cic. Rep. 2.26; Livy 1.20.1-2. Servius at Aen. 2.683 traces the priesthood to Ascanius in Alba. 36 On the oddity in the Roman context of a cooperative priesthood constituted by a mixed-gender pair, see DiLuzio (n. 30), 42-3. Of the flamines only the flamen Dialis' wife discharged priestly functions, and the word flaminica without qualification (rather like flamen without qualification) denotes the wife of the Dialis, RE 6.2490.23-7.

${ }^{37}$ W. Pötscher, 'Flamen Dialis', Mnemosyne 21 (1968), 215-39, makes the clear centrality of the flamen and flaminica's marriage to their cultic function a basis for arguing their role in maintaining fertility, their matrimony an enactment on the human plane of the hieros gamos. The fundamentally cooperative nature of the priesthood is a central theme of the chapter on the flaminica at DiLuzio (n. 30), 17-51, Plut. QR 50, 276d being a key text.

38 See p. 0 below.

${ }^{39}$ J. Linderski, 'Religious aspects of the Conflict of the Orders: the case of confarreatio', in K. Raaflaub (ed.), Social struggles in archaic Rome: new perspectives on the Conflict of the Orders (Malden, MA \& Oxford, 2005), 223-38 makes a persuasive case for confarreatio as an invented tradition, designed to restrict access to the patrician class in the context of the Conflict of the Orders.
} 
marriage, usu,farreo, and coemptione. ${ }^{40}$ This was an elaborate ritual, involving the offering (to Jupiter Farreus) and sharing between bride and groom of far, "emmer-wheat" (in some form of sacramental loaf or cake), on which Pliny the Elder comments (HN 18.3.10) in sacris nihil religiosius confarreationis vinculo erat, 'No ritual is more sacrosanct than the bond of confarreatio.' The flamen Dialis, along with the Pontifex Maximus, also apparently presided over all marriages by confarreatio, and DiLuzio plausibly assumes the presence of the flaminica as well. ${ }^{41}$ The flamen Dialis was not permitted to divorce the wife he had taken by confarreatio, and the alliance was only dissolved by death (Gellius 10.15.23; Plut. $Q R$ 50; 276d, Priscian 5.12, Gramm. Lat.p. 149 Keil): it took the emperor Domitian to stage an appropriately blood-curdling diffarreatio of flamen and flaminica, ritual dissolution of an indissoluble union (Plut, $Q R$. 50, 276e) ${ }^{42}$ If the flamen's wife did die, he was obliged to abdicate: the familial unit that was the essence of the priesthood, focused upon the marital bed (Gellius 10.15.14), at the head of which was a box containing sacrificial cakes, ${ }^{43}$ was thereby terminated. Other respects in which the flaminal couple were held to exemplary standards are harder to extract from the sources, but it seems also to have been stipulated that both flamen and flaminica must have been married just the once, although it is fair to say that the emphasis of the sources is slightly more on the flaminica's status as uniuira. ${ }^{44}$

All of these rules regarding marriage reflect the wider stipulation that the flaminal couple answer to the ideal of an archetypal Roman family. And beyond embodying the ideal

\footnotetext{
${ }^{40}$ Gai. Inst. 1.110, with S. Treggiari, Roman marriage (Oxford, 1991), 16; Linderski (n. 39), 227 and 235 n. 32 ; B. Liou-Gille, 'César, 'flamen Dialis destinatus', REA 101 (1999), 433-59, at 444 for the societal significance of confarreatio.

${ }^{41}$ Serv. Auct. at Virg. Geo. 1.31 with Linderski (n. 39), 233 n. 20; DiLuzio (n. 30), 31-32.

${ }^{42}$ For indications that diffarreatio was at least theoretically available for other farreati couples, see Treggiari (n. 40), 24.

${ }^{43}$ Which rendered the flaminal bed, for Pötscher (n. 37), 227-9, 'das eigentliche Kultzentrum.' The house of the flaminal couple, the flaminia, was a sacred space, Festus terming it an aedes, 79L: DiLuzio (n. 30), 25, and on their bed, 34 .

${ }^{44}$ RE 6.2487.3-16; Liou Gille (n. 40), 443: Ov. Fast. 6.232; Tert. De exhort. cast. 13, De monog. 17; Jer. Ep. 123.8, adv. Iovinian. 1.49; Serv. Auct. at Aen. 4.29. This emphasis on the female party to a marriage is typical of ancient accounts, cf. Treggiari (n. 40), 5: 'There is a tendency, then, to stress the woman's position in relation to marriage, not the man's.'
} 
domestic arrangements, the priesthood was also the authoritative source on marital questions. ${ }^{45}$ It is from the flaminica at Fasti 6.219-34, for example, that Ovid receives the advice he seeks about the timing of his daughter's wedding; and it is also in connection with marriage and its timing that another mention of the flaminica is made, at 3.397-8: in both cases a taboo against marriage coincides with the priestess's physical dishevelment, and in Fasti 6 with an interruption in her marital relations with the flamen, as if the flaminate represents a paradigm for all marriage at Rome. ${ }^{46}$ In a series of articles Boels-Janssen has investigated the flaminate's central function as a model of marriage and guarantee of fertility, with particular reference to the role of the flaminica: most strikingly, her style of hair and hair covering positioned her as the perpetual bride, but also the ideal matrona and materfamilias ${ }^{47}$ The flaminica represented an ideal of the married woman at all stages and all possible statuses. ${ }^{48}$

Marriage and how to define it, where the dividing line lies between honourable and dishonourable sexual relations, is of course a fundamental concern of Aeneid 4. If the flaminate is being evoked by Virgil during the Carthage episode, it is presumably as a model of behaviour to which Aeneas should be aspiring but of which he is, for as long as his affair with Dido persists, falling lamentably short. Comparison with the exemplary marriage of the flamen and flaminica exposes the inadequacy of this relationship as any kind of appropriate marriage for the founder of Rome, then, but it also, as they separate, offers a perspective from which to judge the different perceptions that Dido and Aeneas hold of their liaison. Dido is convinced that they are married, and the reader is allowed plenty of reason to give qualified assent, at least, to her view; but at the same time it seems to matter that the reader can also

\footnotetext{
${ }^{45}$ DiLuzio (n. 30), 29-31,

${ }^{46}$ Cf. DiLuzio (n. 30), 31.

${ }^{47}$ N. Boëls, 'Le statut religieux de la Flaminica Dialis', REL 51 (1973), 77-100; N. Boëls-Janssen, 'La prêtresse aux trois voiles', REL 67 (1989), 117-33; eadem, 'Flaminica cincta: a propos de la couronne rituelle de l'épouse du flamine de Jupiter', REL 69 (1991), 32-50.

${ }^{48}$ On the bridal flammeum worn by the flaminica, see DiLuzio (n. 30), 40-42, 50.
} 
see the force of Aeneas' claim that he was under no obligation to Dido. These seemingly incompatible positions might be clarified if there were different notions of marriage in play. On the one hand there were informal models of marriage in terms of which the Romans could readily understand how Dido might consider the relationship marital: it perhaps resembles most closely an old-fashioned manus marriage $u s u$, the most informal of the manus marriages (marriages which gave the husband all the wife's property, and brought her under his control) which were becoming obsolete by the time of the late Republic. ${ }^{49}$ A marriage $u s u$ was formally constituted, the woman properly in manu uiri, only after a year's cohabitation. But on the other hand, if Roman readers were being encouraged to think in terms of the exacting rules that governed flaminal marriage, confarreatio, this relationship would assuredly not qualify. The need to discriminate between types of marriage, to be able to see the relationship of Dido and Aeneas as plausibly a marriage, yet also equally plausibly failing to meet the criteria of a proper marriage, does seem to be a dilemma that Virgil is posing to us in this book, and if the poet is indeed evoking different, and differentially valued, versions of marriage, that is exactly the effect achieved. It is Dido herself, of course, who early in the book (4.24-9) establishes the status of uniuira as one by which she is to be judged. What we might conclude is that one way in which Carthage is condemned, and Aeneas' presence there along with it, is in standards of behaviour inadequate to a figure as exemplary as the founder of Rome. DiLuzio draws out the exemplary role of the flaminal couple: in Rome 'the organization of the family unit, its internal power dynamics, and its ritual forms represented a microcosm of the res publica,' and the flamen and flaminica gave that societal archetype a sacred expression..$^{50}$

\footnotetext{
49 Treggiari (n. 40), 21 ponders whether Augustus may have had a hand in abolishing usus marriage, while insisting that the general move away from manus marriage in the late Republic was the primary cause of its disappearance. For some of the implications of manus marriage in the case of the flaminica, see DiLuzio (n. 30), 19-20. ${ }^{50}$ DiLuzio (n. 30), 44.
} 
It has been noted that entry to this priesthood had much of the character of a coming of age, and while this represents a less obvious homology between the flaminate and Aeneas' circumstances in Carthage, it is a striking one nevertheless. 'The Diales,' Palmer writes, ${ }^{51}$ 'were caught young.' Livy 27.8.4-10 describes the transformation of C. Valerius Flaccus, a dissolute young man until installed as flamen against his will in $209 \mathrm{BC}$, but thereafter a model iuuenis, noted for the sanctitas of his life. Julius Caesar was around sixteen when abortively named flamen Dialis in succession to L. Cornelius Merula (paene puer, 'barely out of boyhood,' Vell. Pat. 2.43.1), and the successor to Merula eventually appointed under Augustus, Serv. Cornelius Lentulus Maluginensis, was still politically active three decades or more later, thus presumably quite young when appointed: as young as sixteen in $12 \mathrm{BC}$, Palmer reckons. ${ }^{52}$ One of the Scipionic epitaphs commemorates a P. Cornelius Scipio, seemingly a son or grandson of Africanus the Elder, whose life was short, too short to achieve political prominence, but who nevertheless 'wore the apex, mark of the flamen Dialis. ${ }^{53}$ An appointment as flamen Dialis might typically catch one at the onset of manhood, then, but it also carried with it overt semblances of personal emancipation: the appointee was released from his father's potestas (Tac. Ann. 4.16 .2$),{ }^{54}$ in this respect also catapulted into adulthood and responsibility. That Aeneas' story in Book 1, 4, 5 and 6 is shaped by the loss of his father, and by his efforts to fill the space that Anchises' death had left vacant, is uncontroversial. But it is also possible to identify moments when Virgil associates Aeneas at Carthage with figures at a comparable stage of life. If we can read

\footnotetext{
${ }^{51}$ R. E. A. Palmer, 'The deconstruction of Mommsen on Festus 462/464 L., or the hazards of restoration', in J. Lindersky (ed.), Imperium sine fine: T. Robert Broughton and the Roman Republic (Stuttgart, 1996), 75-101, at 86.

52 Palmer (n. 51), 90 n. 69.

${ }^{53}$ CIL i. ${ }^{2} 1.10=6.1288=$ CLE $8=I L S 4=$ ILLRP $311=\mathrm{E}$. Courtney, Musa lapidaria: A selection of Latin verse inscriptions (Atlanta, 1995), no. 11. This by way of contradicting one thread of the compelling discussion of Caesar's near-inauguration by Liou-Gille (n. 40): an anomaly in Caesar's story that requires explanation, she suggests, is his age at the time of these events (see 438, 458). On the contrary, a flamen inaugurated at the cusp of manhood seems to have been the norm.

${ }^{54} R E$ 6.2486.33-5.
} 
Scipio Africanus the Elder's exploits in Spain into Aeneas' arrival at Carthage in Book 1, for example, an important point of correspondence between them is that they are both ostensibly inexperienced men emerging from the shadows of their fathers. ${ }^{55}$ Carthage is a test for the new leader, one which, ultimately, he successfully negotiates. I am suggesting that Virgil colours this crisis of new-found responsibility undergone by Aeneas with the associations of the religious office that took $\mathrm{C}$. Valerius Flaccus from dissolute youth to a status that, as we shall soon see, was equivalent to nothing less than a guarantee of the future prosperity of Rome. The flaminate stands in polar opposition to a disorderly life: the flamen is castus Iouis sacerdos, 'the pure priest of Jupiter,' while his wife is coniunx sancta Dialis, 'the blameless

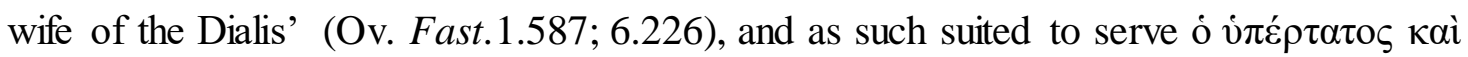

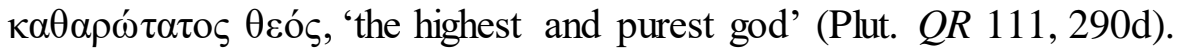

Before attempting to isolate the fundamental character of the flaminate we might return, in even more overtly speculative spirit, to the topic of the flamen's clothing. A lot here depends on how we interpret Virgil's words demissa ex umeris. There are intriguing analyses of the phrase in James Henry's Aeneidea, offering two contradictory readings. ${ }^{56}$ In one note, emphasising the ex expressing 'change of position', from off, Henry asserts that the laena is 'not by any means hanging from his shoulders, but let down off his shoulders, lowered so as no longer to cover the shoulders.' In a second note, however, Henry takes ex as equivalent to $a b$, and concludes that the whole phrase does indeed simply mean hanging from his shoulders: certainly at Sil. Pun. 15.421-2, where Silius evokes this moment in Aeneid 4 as he describes Hasdrubal celebrating the anniversary of the foundation of Carthage (fraternum laena nitebat/demissa ex umeris donum, 'a laena, the gift of his brother, blazed, sweeping down from his shoulders'), there is no suggestion of a garment improperly worn. Perhaps, in

\footnotetext{
${ }^{55}$ V. S.-R. Shi and Ll. Morgan, "A Tale of Two Carthages: History and Allusive Topography in Virgil's Libyan Harbor (Aen. 1.159-69)," TAPhA 145 (2015), 107-33, at 124-5.

56 J. Henry, Aeneidea II (Dublin, 1878), 684.
} 
fact, like the suggestively ambiguous expression at Aen. 1.404, pedes uestis defluxit ad imos, from which Reckford launches his brilliant analys is of Virgil's Venus, a 'great and dangerous goddess', we are not meant to choose definitively between these options: did the goddess' 'dress flow down to her feet' or 'slip down to her feet' in disturbingly erotic fashion as she parted from her son and revealed her true nature ${ }^{57}$ What makes this question of exegesis in Book 4 potentially significant is the importance that attached to the scrupulously proper dress of the flamen and flaminica, both of whom will have seemed noticeably over-dressed by comparison with other Romans. It is clear enough in the sources that the flamen's garb, his insignis uestis, 'characteristic clothing' (Livy 1.20.2), was a conspicuous distinguishing feature of the priesthood. ${ }^{58}$ That includes the bulky laena, but even more key to the identity of the flamen was his distinctive headwear, the apex, a leather cap or galerus made from the hide of a white bull sacrificed to Jupiter, topped with a pointed length of olive wood on a base surrounded by a lock of wool, the latter the apex proper. ${ }^{59}$ This hat, as possibly the laena (cf. Servius Auctus at Aen. 8.552), was worn perpetually by the flamen Dialis, outdoors at least. ${ }^{60}$ To set the apex on someone's head could mean to appoint them flamen Dialis (Livy 6.41), while Q. Sulpicius in $223 \mathrm{BC}$ was obliged to resign from the priesthood because his apex fell off as he was sacrificing (Plut. Marc. 5; Val. Max. 1.1.5; cf. Plut. $Q R$ 40, 274c, Gellius 10.15.17). ${ }^{61}$ L. Cornelius Merula, according to Appian (BC 1.8.74), removed his apex

\footnotetext{
${ }^{57}$ K. J. Reckford, 'Recognising Venus (I): Aeneas meets his mother,' Arion 3 (1995-1996), 1-42. 58 Jullien (n. 30), 1167-1169.

${ }^{59}$ Cf. the lanigeri apices on Aeneas' shield, Aen. 8.664, in effect a gloss on the word flamen, which was supposed to derive from this woollen filum: R. Maltby, A lexicon of ancient etymologies (Leeds, 1991), s.v. "flamen."

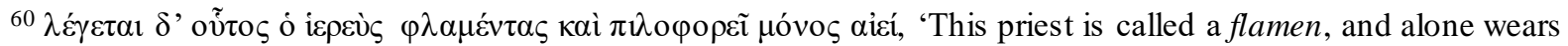
a cap at all times,' App. $B C$ 1.8.65; cf. Varro LL 5.84; Gellius 10.15.17: Liou-Gille (n. 40 ), 439 n. 37 interprets Appian's comment as a reference to the especially pious character of the flamen Dialis L. Cornelius Merula (on whom see pp. 0-0 below), but in fact Appian is clearly referring to the priesthood of the flamen Dialis in general. The flaminate could be evoked on coins by the apex alone, Vanggaard (n. 30), 71-2.

${ }^{61}$ At 12.492 Aeneas' helmet has an apex that is knocked off in advance of what R. Tarrant, Virgil, Aeneid XII (Cambridge, 2012), at 494-9 calls 'a critical moment in the narrative', a potential parallel to this significant change in status.
} 
before killing himself in $87 \mathrm{BC}$ in order that the flamen Dialis might not come into contact with death. ${ }^{62}$

The corollary of these very strict dress requirements was a strong taboo against undress. We find similar accounts in Gellius and Plutarch, in both cases relating the prohibition to the flamen's proper deportment in the sight of Jupiter, the latter identified with the open air (Gellius 10.15.20, tunica intima nisi in locis tectis non exuit se, ne sub caelo tamquam sub oculis Iovis nudus sit, 'He does not remove his inner tunic except indoors, so as not to be naked beneath the open sky, as if under the gaze of Jupiter'; cf. Plut. $Q R$ 40, 274ab). Jupiter is of course the god whom the flamen Dialis serves, and improper attire is an affront to him. As Lyne suggests, Aeneas' clothing is part of what causes Jupiter's messenger such outrage when he sets eyes upon him, ${ }^{63}$ and a gaudily decorated laena might be enough to achieve this. From Servius we learn that the laena had to be made entirely of wool, and indeed that a flaminica once committed a serious piaculum by adulterating the wool of a laena with linen: ${ }^{64}$ Dido's addition of gold thread is presumably all the more reprehensible. But if Henry's first reading has any plausibility, if Aeneas as he labours to build Carthage has let his priestly garment down from his shoulders, that failure to observe the decorum of flaminal dress is itself an affront to the god he is supposed to serve. It is obviously the case that at this juncture Aeneas is in other respects exposed to the outraged gaze of Jupiter. It is equally clear that baring the shoulders is no affront to the god in a context that is not

\footnotetext{
62 The arguments of Palmer (n. 51) towards reconstructing the text of Festus (and the events of 223 BC) to some extent hang upon the rules regarding a flamen Dialis' headwear. For the avoidance of death, see Gellius 10.15.24, locum, in quo bustum est, numquam ingreditur, mortuum numquam attingit, 'he never approaches a place where there is a funeral pyre, nor touches a corpse'; and for related taboos on touching (or in some cases even naming) raw meat, fermented bread, beans, dogs, and horses, or overhearing the flute accompaniment to a funeral, see Jullien (n. 30), 1157.

${ }^{63}$ Lyne (n. 20).

${ }^{64}$ Serv. Auct. at 12.120; DiLuzio (n. 30), 37.
} 
informed by the peculiar prohibitions of the flaminate, as Aeneas' gesture at 5.685-6 illustrates.

Another respect in which Atlas bears comparison with Aeneas, it might be added, is in the attention given to the Titan's physicality and attire. A contrast is clearly in play between Aeneas in Carthage and the unyielding Atlas past whom the narrative has just carried Mercury, and it is partly activated by reference to the shoulders of the hero to which the phrase demissa ex umeris, whatever else we make of it, necessarily calls our attention. Shoulders of course have a claim to be the quintessential heroic body part in the Aeneid: familiarly, toward the end of Book 2 (721-25) and at the very end of Book 8 (729-31), Aeneas lifts onto his shoulders burdens that represent his vast responsibilities, the continuation of Troy in the shape of Anchises clutching the sacra ...patriosque Penatis (2.717), and the Roman future represented and promised on the shield. In each case, as Hardie has done most to clarify, ${ }^{65}$ the poet's emphasis on Aeneas' load-bearing shoulders, not least, activates associations with Atlas and his close conceptual counterpart Hercules, each in turn figures for resilience and philosophical enlightenment well established in Stoic tradition. In fact, as Hardie points out, there is a third instance of shouldering to set alongside these, 'the burden carried by the giant Atlas on his shoulder' at 4.481-2=6.796-7 and 8.136-7; and at 4.247 too Atlas' 'sky-bearing is also mentioned', ${ }^{66}$ unavoidably reasserting the symbolic force of burden-bearing, again with reference to shoulders (4.250), immediately before Mercury's epiphany. Down below in Carthage, Aeneas' shoulders are also called to our attention, and we are asked to contemplate what symbolic burden they are, are rather are not, at this moment bearing. It is noticeable also, however, that Atlas when Mercury visits him is a very encumbered figure: he has an apex (246), his head is perpetually wreathed in cloud

\footnotetext{
65 Hardie (n. 4), 369-76.

${ }^{66}$ Hardie (n. 4), 372. The clear distinction Hardie draws at n. 112 between Atlas the mountain and Atlas the giant perhaps gives inadequate weight to the careful ambiguity of Virgil's description.
} 
(248-9), and his shoulders are covered with snow (250). Aside from any other association, that is potentially not unlike a flamen, swathed in a thick woollen laena, the apex never leaving his head.

A broader view of the existential status of the flamen Dialis may suggest a more fundamental kinship between the ideals to which Virgil encourages us to hold Aeneas and the austere lifestyle of this priest. As his constant wearing of the apex (and possibly laena) implies, he was allowed no respite from his duties: a Ioui adsiduus sacerdos, 'perpetual priest for Jupiter' (Livy 1.20.2), the Dialis cotidie feriatus est, in the words of Gellius (10.15.16). 'Constantly on holiday' of course means free of the everyday responsibilities of ordinary men - and perpetually in service to the god. The most noteworthy restriction on his activity in this connection was that of physical mobility: the flamen was essentially confined to the city of Rome, ${ }^{67}$ with a particular focus on the flaminal bed: ${ }^{68}$ that bed had its feet symbolically smeared with mud or clay (Gellius 10.15.14), grounding the flamen in his native soil. Scheid describes the flamen as 'comme enraciné dans le sol de Rome', ${ }^{69}$ Dumézil as 'la gage de la prospérité économique et politique de la communauté.' The 'ritual program' of the flamen and the flaminica, writes DiLuzio, 'was crucial to the continued wellbeing of the Roman state, and the prohibitions associated with their priesthood provided a safeguard against the possibility that this program should lapse. ${ }^{70}$ What flaminal clothing might evoke above all else, then, is an archetypal expression of Roman identity. Aeneas is also rooted in a city when Mercury visits him, and defending its interests to the extent of directing its foundation. But this is not Rome that the laena-clad hero is associating himself with, and not just not Rome:

\footnotetext{
${ }^{67}$ Livy 5.52 records a prohibition against the flamen even spending a single night away from Rome; Gellius 10.15.14 speaks of a ban on three days away from his bed and Plut. $Q R 40,274 \mathrm{c}$ of more than three, while Tac. Ann. 3.71.2-3 allows for two days' absence twice per year in case of illness, but absence from ritual duties rather than necessarily the city, it seems: Vanggaard (n. 30), 64-6.

68 See p. 0 and n. 43 above.

69 J. Scheid, Religion et piété à Rome (Paris, 2001), 56.

70 DiLuzio (n. 30), 32.
} 
Carthage is the enemy city, the anti-Rome. If we indeed are being made to think of a priest so intimately concerned with the welfare of Rome, this circumstance is quite stunningly wrong, and the nature of its wrongness mercilessly exposed by comparison with the ultimate paradigm of exemplary Roman behaviour.

His intensely ritualized circumstances leave the flamen Dialis with both a peculiar passivity and a profound ambivalence of status. On the one hand he is prematurely emancipated from his father's control, and free of mundane ties: for all the restrictions, which certainly made a conventional political career effectively impossible, ${ }^{71}$ the flaminate remained an office of immense prestige, 'object of the highest esteem' with a 'status' that 'was awe-inspiring. ${ }^{72}$ On the other hand, however, the Pontifex Maximus's co-option of the flamen can be described by the term capere, as if of a prisoner by an enemy. ${ }^{73}$ Utterly free, utterly restricted: the flamen Dialis represents an extreme case of attempting to render a man sacer (belonging to the gods) by sundering him from the profane, a condition encapsulated by the wand or commoetaculum (visible on the south frieze of the Ara Pacis) with which the flamen kept the general populace at a distance from his sacred person. ${ }^{74}$ Plutarch arrestingly

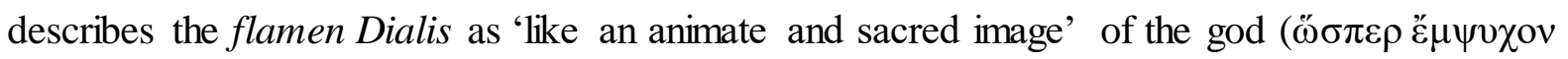

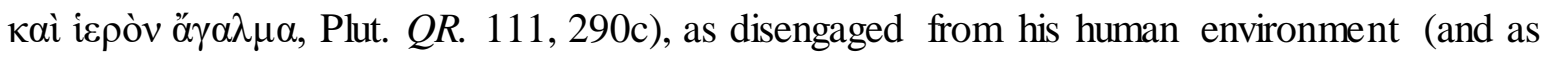
identifiable with his god) as a cult statue, while Gellius (10.15.32) quotes Varro's Rerum

\footnotetext{
${ }^{71}$ L. Cornelius Merula was seemingly the only flamen Dialis to hold a consulship under the Republic, LiouGille (n. 40), 437, and that was under the most unusualcircumstances. After Cinna's expulsion from Rome, Merula assumed the consulship largely, no doubt, because as flamen Dialis it was felt no one would dare lay a finger on him, as brilliantly explained to me by Professor Roberta Stewart in person. Tac. Ann. 3.58-59 and 71 detail the attempts of Ser. Cornelius Lentulus Maluginensis, Augustus' appointee as flamen Dialis, to enjoy some of the benefits of a conventionalcareer. He had been consul in AD10.

72 Vanggaard (n. 30), 82. The dictator Sulla made something of the fact that his ancestor the first Sulla was also flamen Dialis: Gellius $1.12 .16=F R H 22$ fr. 2; M. S. Bassignano, 'Il flaminato nella politica romana fino all'età di Tiberio', AIV 125 (1966/7), 241-90, at 252-3.

73 Linderski (n. 51), 228 and 236 n. 41; Gellius 1.12.15-6, with Liou-Gille (n. 40 ), 447 and 452 n. 116. Capere is used of the selection of C. Valerius Flaccus by the Pontifex Maximus at Livy 27.8.

${ }^{74}$ Cf. P. Rehak, 'The fourth flamen of the Ara Pacis Augustae', JRA 14 (2001), 284-8, at 287: 'Each of the foreground flamines' on the south frieze of the Ara Pacis 'occupies his own space and is not overlapped by other figures, in keeping with the special sanctity of his office.'
} 
Divinarum (fr. 4 Merkel) for an explanation of the colour of the flamen's cap: is solum album habet galerum, vel quod maximus, vel quod Iovi immolata hostia alba id fieri oporteat, 'He alone has a white cap, either because he is the greatest priest, or because a white victim must be sacrificed to Jupiter.' Both godlike and like an offering to the god: again, the resonance with Aeneas in the remainder of Book 4, his strange isolation and emotional self-discipline, and his ambiguous status, the heroic leader in thrall to divine will, is striking. It has seemed something of a paradox, and a paradox it undoubtedly is: but potentially a paradox which made good religious sense, and indeed represented a powerful ideal, to a Roman reader.

In summary, we have in the flaminate an institution that is intimately concerned with the welfare of Rome, and that requires the most exemplary standards of behaviour from its incumbents, and does so in some areas at least that correspond in highly suggestive ways to the Aeneas' circumstances in Aeneid 4. It would undoubtedly lend an intense clarity to the scandal of Aeneas's position at this moment, engaged as he is in the construction of Carthage, and entirely oblivious of Jupiter's purpose for him, if the relationship of the flamen Dialis to his god, and the guarantee it carried of Rome's success, is being evoked.

\section{IV}

The commentary tradition represented by Servius, and in the main here we are looking at the amplified commentary known as Servius Auctus, ${ }^{75}$ was certainly convinced that Aeneas was a flamen. Amid its consistent interest in Aeneas' religious accomplishments (Aeneas is omnium sacrorum et peritus et primus, 'skilled and foremost in religious matters,' at Aen. 8.552), there is especial attention given to the flamen and flaminica Dialis, ${ }^{76}$ and

\footnotetext{
75 The seminal account of the versions of Servius that have come down to us remains G. P. Goold, 'Servius and the Helen Episode', HSCPh 74 (1970), 101-168.

${ }^{76}$ Cf. Starr (n. 30), 64-5.
} 
reference is made to this priesthood in the commentary to every book of the Aeneid bar 5, 6 and 9: an annotated list of occurrences, providing an impression of the character of the Servian interest in the flaminate, can be found in an appendix. But Servius Auctus on Book 4, in both frequency and extent of flamen-related notes, is of an entirely different order. ${ }^{77}$ Most interestingly of all, the commentary itself identifies Aeneid 4 as a book disproportionately interested in flamines. At Aen. 1.305 and 12.492, where the issue is the apex, the flamen's characteristic headwear, we are directed to Book 4 for a fuller account (quod in quarto plenius dictum est, 'as was explained at greater length in the fourth book,' 12.492: a fuller treatment of the flaminate in general is meant rather than just of the apex, it seems) 'in its proper place' (loco suo in quarto libro, 1.305). It is certainly worth wondering what could possibly make Aeneid 4 the 'proper place' for information about the flaminate.

The general view expressed in Book 4 is encapsulated in uncompromising terms at 4.103, sciendum tamen in hac conuentione Aeneae atque Didonis ubique Vergilium in persona Aeneae flaminem, in Didonis flaminicam praesentare, 'but it it is to be understood that in this marriage of Aeneas and Dido Virgil presents the flamen in the role of Aeneas, and the flaminica in that of Dido.' The laena at 262 is identified as a flaminal hint, although flaminal hints are found in plenty of other places as well: a glance at the appendix will illustrate the mix in the tradition of plausible and wildly tenuous interpretation. What lends value even to the more outlandish individual notes, however, is the guiding assumption it reveals in the commentary, especially in Book 4, that allusions to the flaminate are there to be discovered. Something more prominent in Servius' account than in mine thus far is Dido in the role of the flaminica, at least as important an identification as far as the commentary

\footnotetext{
${ }^{77}$ M.-K. Lhommé, 'Pontifes et flamines dans le commentaire de Servius à l'Énéide', in A. Garcea, M.-K. Lhommé and D. Vallat (eds.), Fragments d'érudition, Servius et le savoirantique (Hildesheim, 2016), 369-394, at 374 . One consequence of the commentary's preoccupation with the priesthood is that Servius is, alongside Plutarch and Gellius, a major source of information on the flaminate.
} 
tradition is concerned as Aeneas with the flamen. Thus at Aen. 4.646, sane quidam uolunt, Vergilium ubique Didonis tamquam flaminicae facere mentionem, 'Certainly some have it that Virgil alludes everywhere to Dido as flaminica.' There are potentially interesting things to say about Dido as flaminica, though our evidential basis is especially thin. A suggestive

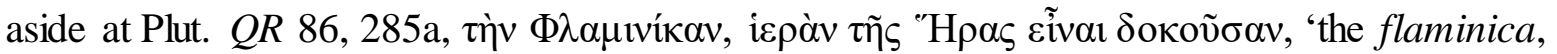
thought to be sacred to Hera,' records a perception of her as bearing the same relation to Juno as the flamen to Jupiter. Vanggaard sees this as both contradictory of the fundamental religious logic of the flaminate and also something that the ancients, often almost as mystified by their religious observances as we are, might well have been ready to entertain: it would certainly suit Dido, and Virgil's symbolic dichotomies between Carthage and Rome, Dido and Aeneas, Juno and Jupiter. ${ }^{78}$ The Carthaginian queen as flaminica would also represent a fascinating counter-current to Dido the representative of definitively Punic religious practice, especially the votive human sacrifice that her final self-immolation seems to establish as her legacy. ${ }^{79}$ If the trajectory of Book 4 is toward a realisation of a recognisable Carthage, one that would engender Hannibal, and concomitantly a clarification of the values that would bring Rome into existence, it would seem that Aeneas' progression

\footnotetext{
78 Vanggaard (n. 30), 31.

${ }^{79}$ S. Lancel, Carthage, a history (Oxford, 1995), 24 finds in the myth of Dido's death 'the outlines of the religious practice of self-sacrifice which a Phoenician king or queen was obliged to carry out in a grave crisis,' of which 'the sacrifice of children by fire in the tophet was perhaps only a ritual derivation', comparing Appian's account of the death of the Carthaginian commander Hasdrubal's wife after the city's capture in 146 BC: she killed her children and threw them into a burning temple, then jumped in herself (8.131). J. Davidson, 'Domesticating Dido: history and historicity', in Burden (n. 4), 65-88, at 72-7 identifies the 'grave cris is' that might have motivated Dido's original self-sacrifice in Punic myth as a threat 'from outside by the African king', in response to which 'Dido offers up herself in return for the city's salvation', and plays down the difference between the child sacrifice most associated with Carthage and an adult's self-immolation: 'Is not the offering up of one's own children the greatest act of self-sacrifice?' The most striking thing about Virgil's take on this mythic and historical material is, as Davidson insists, his resistance to the impulse to demonize Carthage and its queen, but Carthage becomes recognisably Rome's most threatening rival by the close of Book 4, and well before then the poet already appears to be manipulating his readers' as sumptions about Carth age and its religious practices: Venus' concern for Ascanius' wellbeing in Carthage, for example, would seem to echo anxieties the Roman reader might harbour about the safety of children there. Saturnia as a name for Juno, apparently coined by Ennius (fr. 53 Skutsch) might indeed suggest the future favour the goddess would show the Saturnia terra (Skutsch ad loc.), but Iuno Saturnia is also quite close to TNT PN B'L, "Tanit face of Baal" (Saturn was the Roman identification for Baal, as Juno for Tanit), the name commonly given the goddess at the tophet in Carthage: Lancel (this note), 199.
} 
toward disciplined self-denial and Dido's toward irrational vengeance has a religious

dimension as well, Dido inaugurating the sacrificial enormities of Tanit, while Aeneas

becomes the first flamen of Jupiter. Perhaps the clear dichotomy between Rome and Carthage achieved by the end of Book 4 is precisely captured as Aeneas sails away from Dido's pyre, obeying a flaminal taboo against any locus in quo bustum est, 'place in which there is a funeral pyre' (Gellius 10.15.24) even as she inaugurates Punic human sacrifice. ${ }^{80}$

Looking to support from Servius nevertheless remains a bold argumentative strategy, especially as I would freely acknowledge that the vast majority of instances where Servius finds allusion to the flamen or flaminica are profoundly unpersuasive. ${ }^{81}$ The quite extensive scholarship on Servius' flamen-fixation agrees: none of that scholarship entertains the possibility that Virgil really wanted us to think of the flamen Dialis in connection with Aeneas, or Dido and Aeneas. ${ }^{82}$ But what are we to make of such an intense interest in the priesthood at this particular point of the poem, disproportionately present in that thread of the commentary tradition which is apt, once in a while, to throw up material of greater antiquity and authenticity? ${ }^{83}$

\footnotetext{
${ }^{80}$ For Dido represented as flaminica we have her weaving of Aeneas' laena in the manner of a self-sufficient flaminica. But there may also be a hint at 4.139, where Dido wears a purple garment underpinned with a golden fibula. We have encountered fibulae already in the costume of the flamen, p. 0 above. N. Boëls-Janssen, 'La prêtresse aux trois voiles', REL 67 (1989), 117-33, at 125 discusses the uenenatum worn by the flaminica, relating it to the suffibulum worn by the Vestals (Festus 474L), the name of the latter garment deriving from the fibula that gathered it on the Vestal's chest. Boëls-Janssen also remarks on the originally sacred character of the fibula itself.

${ }^{81}$ For a detailed analysis of four such notices in Servius, see Starr (n. 30), 66-8.

82 J. W. Jones, 'Allegorical interpretation in Servius', CJ 56 (1961), 217-26; Starr (n. 30); A. Sharrock, 'Aemulatio: the critic as intertext', in S. Casali and F. Stok, Servio: stratificazioni esegetiche e modelli culturali (Brussels, 2008), 7-23; K. Fanciullacci, Aeneas as the Flamen and Flaminica in the Servian Commentary on Vergil's Aeneid, Master of Arts dis sertation, University of Kansas, 2012; M.-K. Lhommé, 'Pontifes et flamines dans le commentaire de Servius à l'Énéide', in A. Garcea, M.-K. Lhommé and D. Vallat (eds.), Fragments d'érudition. Servius et le savoir antique (Hildesheim, 2016), 369-94: at 394, 'Cet ensemble de commentaires témoigne de l'existence d'une communauté de savants quispéculent, de façon parfois très sophistiquée (mais aussimaladroite), sur la religion romaine archaïque, sentie comme culture commune.'

${ }^{83}$ F. Stok, 'Commenting on Virgil, from Aelius Donatus to Servius', Dead Sea Discoveries 19 (2012), 464-84, at 469-74 considers the different emphases of Servius and Donatus, the latter being the presumptive source of such additional material introduced in the Servius Auctus commentary as the flaminal material of Book 4 and elsewhere. Servius' exclusion of this material betrays his target audience of schoolboys and his primary aim of teaching the Latin language, whereas Donatus was 'the one who taught the advanced classes': Goold (n. 75), 135. In addition, however, between Donatus and Servius fell the edict of Theodosius in 391, banning all
} 
It may be of incidental relevance to this question that the flamonium Diale was an issue of some urgency in Augustan Rome. The notion that Augustan religious policy might find a reflection in the Aeneid, and in Aeneas' religious practice especially, is familiar. ${ }^{84}$ In the case of the flamen, the city had lacked a priest who could without difficulty be understood as critical to its wellbeing since $87 \mathrm{BC}$, when L. Cornelius Merula had taken his own life in the context of civil conflict between Sulla and Marius and Cinna. Julius Caesar had apparently been designated as Merula's successor shortly afterwards but never inaugurated, the enactments of Marius and Cinna being subsequently annulled by Sulla on his recapture of Rome. ${ }^{85}$ Eventually, in 12 or $11 \mathrm{BC}$, a new flamen Dialis was at long last appointed, and it is reasonable to suppose that much was made of this inauguration. The Ara Pacis shows four flamines (the three maiores and the flamen of Julius Caesar, presumptively), the one brandishing the commoetaculum perhaps being the flamen Dialis: if there were no priest in office at the dramatic date of the scene, this is an interesting fiction, but the issues surrounding the dating of the procession depicted are controversial. ${ }^{86}$

The eventual appointment of a flamen Dialis under Augustus, notwithstanding some controversy about this date also, ${ }^{87}$ looks like a crowning gesture after Augustus had finally

expressions of pagan cult. Servius' commentary, even though its author was not Christian, 'not only refers to the pagan rites as a phenomenon of the past, but shows much less interest in them than Donatus had': Stok (this note), 473.

${ }^{84}$ See most recently V. Panoussi, 'Aeneas'sacral authority,' in J. Farrell and M. C. J. Putnam, A companion to Vergil's Aeneid and its tradition (Chichester, 2010), 52-65, which however states incorrectly that Augustus became both pontifex maximus and flamen Dialis (53), rejects the possibility that Aeneas evokes the latter priesthood (54), and in its book-by-book survey of the poem sidelines Aeneid 4 (56).

${ }^{85}$ Liou-Gille (n. 40); Vanggaard (n. 30), 51. It is unclear by precisely what procedure Caesar's inauguration was prevented, Liou-Gille (n. 40), 456. It is also a reasonable suspicion that the long hiatus in the priesthood after Merula's death had something to do with Caesar's deposition, Liou-Gille (n. 40), 438.

${ }^{86}$ Rehak (n. 74).

${ }^{87}$ G. Bowers ock, 'The pontificate of Augustus', in K. A. Raaflaub and M. Toher (eds.), Between Republic and Empire (Berkeley, 1990), 380-94. 
managed to assume the role of Pontifex Maximus in $12 \mathrm{BC}$ with the death of M. Aemilius Lepidus. A parallel is Augustus' activity in the area of civic time ${ }^{88}$ also undertaken in his capacity as Pontifex Maximus after $12 \mathrm{BC}$, including the construction of the so-called Horologium in the Campus Martius, described by Haselberger as 'a powerful demonstration of his being in charge of the Roman calendar and bringing civic life into order, in agreement with the solar cycle and the heavens. ${ }^{89}$ One can imagine how the lack of a flamen Dialis before that date could in similar fashion represent, or be made to represent, a lingering element of disorder in Rome's relations with its gods, ${ }^{90}$ and that the subsequent appointment of Ser. Cornelius Lentulus Maluginensis could in contrast convey a profound implication of renewed stability. ${ }^{91}$ An analogy between an absent flamen Dialis in contemporary Rome, prominent in the Augustan narrative, and an absent-but-emerging flamen in the shape of Aeneas would also be characteristic enough of Virgil's practice in the Aeneid. ${ }^{92}$

But there may be a stronger case to be made for the flaminate as a focus of interest and anxiety in the Augustan era. Liou-Gille's discussion of the death of Merula in $87 \mathrm{BC}$ takes at face value the terms of Velleius' account of Merula's death. ${ }^{93}$ As he died, according to Velleius (2.22.2), Merula reversed the poles of his flaminal power, so to speak, pronouncing a curse upon Cinna partesque eius that the historian presents as the opposite of

\footnotetext{
88 Suet. Aug. 31.1-2.

${ }^{89}$ L. Haselberger (with responses by P.J. Heslin and M. Schütz and additional remarks by R. Hannah and G. Alföldy), 'A debate on the Horologium of Augustus: controversy and clarifications', JRA 24 (2011), 45-98, at 69. This collection of articles captures well the history and current state of this highly controversial subject. What is uncontroversial is that Pliny the Elder ( $H N$ 36.71-73) describes a monument associated with an Egyptian obelisk as a gnomon, designed for 'observing the shadows of the sun, and thus the lengths of both days and nights,' which also in some manner tracked the passage of the year by the length of shadow cast, and that Pliny's account is broadly compatible with archaeological discoveries. The obelisk was erected, as the identical inscriptions on two sides of its pedestal indicate, by Augustus as Pontifex Maximus in 10/9 BC (47-8).

${ }^{90}$ M. Beard, J. North and S. R. F. Price, Religions of Rome (Cambridge, 1998), Vol. 1, 131.

${ }^{91}$ Suet. Aug. 31.4 includes the Diale flamonium among rituals including the Lupercalia and Secular Games that Augustus had rescued from disuse.

92 Mark Antony, an acknowledged presence in the portrayal of Aeneas in Book 4, had been immortalized by Cicero in the Second Philippic as a notably disreputable flamen designatus (110-111), in his case flamen of the deified Caesar, although Dio (44.6.4), for what it is worth, claims that Antony as flamen Julialis was a kind of distorted flamen Dialis, broadly comparable to my reading of Aeneas. See Vanggaard (n. 30), 85, and S. Cole, Cicero and the rise of deification at Rome (Cambridge, 2013), 170-84.

93 Liou-Gille (n. 40).
} 
his conventional role, that of praying to Jupiter for the salus rei publicae. The subsequent attempt to make Caesar flamen Dialis, according to Liou-Gille, was an effort on Cinna's part to disarm or evade the flamen's execratio. But given that Caesar was only ever designated, and never inaugurated, Rome remained without its spiritual hotline to Jupiter, and rather worse, the curse on Cinna and his party potentially persisted, unpropitiated. If a curse on 'Cinna and his party' could be felt as directed at Caesar, and it surely could, it might also hang over the heir of Caesar, a severe and unresolved crisis in relations between Rome and its gods that Augustus is only finally able to correct in $11 \mathrm{BC}$. Whether or not that is a plausible reading of contemporary religious anxieties, the late-Republican crisis of the flaminate looks like an issue that Virgil, some way in advance of $11 \mathrm{BC}$, might well see fit to broach.

\section{VI}

The possibility of a contemporary resonance is not the strongest argument for the case I am constructing, but equally none of my other strands of evidence, independently, is decisive either. It would be uncontroversial to believe that Servian commentary on the Aeneid has more to do with fourth- or fifth-century perceptions of Virgil than with the poet's own designs, while the analogies between Aeneas' circumstances in Carthage and key functions of the flaminate of Jupiter, though (I would insist) striking, can only establish a very broad kind of correspondence, a correspondence furthermore the precise workings of which within Virgil's text must necessarily escape us. It is all, in the last analysis, a lot to build on a single piece of clothing, an isolated lexeme in the Virgilian text, however resonant they each may be. But while acknowledging the necessarily speculative nature of this exercise, I might in turn ask what better explanation there is of this accumulation of unrelated intimations of a flaminal theme in Aeneid 4. 
If we can accept the plausibility of this reading, on the other hand, the payoff for our appreciation of Virgil's Carthage episode is considerable. We would have identified in Aeneid 4 a significant mechanism for defining the status of Aeneas' behaviour, by which I mean a powerful method for Virgil to guide the Roman reader's perception of his hero. By setting Aeneas' (and seemingly Dido's) actions against a model of behaviour embodying some of the most profoundly respected expressions of Roman culture, a paradigm both of moral exemplarity and national identity, the poet establishes an intensely meaningful frame for their encounter. From this love affair between the founders of the two great Mediterranean rivals, and from their separation, emerges, in Virgil's telling, the clear and unbridgeable distinction between the two peoples. If Dido in her death realises the hints of Carthaginian religion that Virgil has allowed to surface periodically during Aeneas' visit, especially the aspects of Carthaginian cult that most appalled the Romans, the evocation of equally fundamental Roman ritual institutions fills out the opposing side of that polarity, the rigid principle and devotion to Jupiter that the Romans imagined was key to their civilization and success. Ultimately, of course, I would claim that flaminal colouring functions as a yardstick, a singularly austere measure, to which we are encouraged to hold the compromised Aeneas, and a reminder of what he will bring into existence once free of this entanglement with Carthage — what Rome, in its very essence, is.

Other non-negligible implications follow from this argument. If the richness of the Aeneid's poetic texture hardly needs further illustration, the semiotic potency of clothing in a Roman context still perhaps benefits from attention in literary analysis, as does the overwhelming importance of religion, Rome's preoccupation with its relations to the gods, in all forms of Roman cultural expression. Servius, finally, is an inextricable part of this interpretative exercise, and while it cannot claim to offer any clear guidance to exploiting the commentary tradition for reconstructing Virgil's design, it is nonetheless a reminder that the 
material thereby preserved is potentially just as valuable to the first century $\mathrm{BC}$ as to the fourth or fifth $\mathrm{AD}$, recording as it does, in however distorted a form, whispers barely discernible by other means.

\section{$\underline{\text { Appendix }}$}

A tabulation, and brief summary, of references to the flaminate in Servius' commentary on the Aeneid, book by book. Material from Servius 'Auctus' is specified as such.

Serv. Auct. at 1.179: a taboo against the flamines coming into contact with leavened flour is read into the Trojans' preparation of food after the storm; at 1.290: mention is made of the flamen attached to Julius Caesar's cult; Serv. Auct. at 1.305: Aeneas' bare-headed state in daytime is presented as appropriate to a flamen, according to rules governing the priest's headwear only mentioned here; at 1.448: the bronze fittings of Juno's temple are explained through the sacred associations of the metal, illustrated by the requirement that the flamen Dialis' hair or beard be trimmed with a bronze knife; Serv. Auct. at 1.706: the loaded table set before Aeneas is stated to be felt by some to evoke a rule that the flamen Dialis should never be presented with an empty table;

Serv. Auct. at 2.76: the removal of Sinon's chains at Priam's instruction is related to the rule that any shackled person entering the flamen's house is relieved of his chains (cf. Aul. Gell. 10.15.8); at 2.683: the proper sense of the word apex is given as the rod wound around with wool on the top of the flamen's hat, and the establishment of the flaminate is attributed to Ascanius at Alba;

Serv. Auct. at 3.607: a prohibition against whipping anyone who is embracing the feet or knees of the flamen is adduced as a parallel for Achaemenides' treatment by Aeneas and Anchises (cf. at 2.76); 


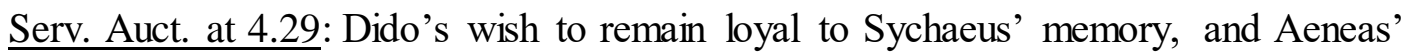
marital history and future, are assimilated to the rules governing the marriage of flaminica and flamen, stated here to be that the flaminica might only wed once, and the flamen only after the death of a previous wife; Serv. Auct. at 4.103: the terms used in Juno's anticipation of a marriage between Dido and Aeneas are traced to Roman marital practice, both coemptio and confarreatio, the latter suggestion concluding sciendum tamen in hac conuentione Aeneae atque Didonis ubique Vergilium in persona Aeneae flaminem, in Didonis flaminicam praesentare; Serv. Auct. at 4.137: a long note arguing that Dido's clothing for the hunt evoked the dress of the flaminica; Serv. Auct. at 4.262: another long note that discusses the laena Aeneas is wearing, describing the garment, making the connection with the flamen and further connections with Venus and the Laenates, noting that the flamen's laena was woven by the flaminica, and linking Aeneas' elaborate sword with the secespita or sacred knife that the flamen, among others, carried; Serv. Auct. at 4.263: the character of Aeneas' clothing is said to suggest the dress of a lover, and it is stated again that the flaminica, like Dido, weaves the flamen's clothes; Serv. Auct. at 4.339: Aeneas is interpreted as effectively arguing from a definition of marriage: this cannot be a proper marriage between Dido and Aeneas because it is not marriage by confarreatio: the thunder present at their encounter in the cave is also said to invalidate a confarreatio wedding; Serv. Auct. at 4.374: locaui is read as an allusion to the terminology of confarreatio; Serv. Auct. at 4.518: more details of the flaminica's dress are cited which Dido's dress is claimed to evoke; Serv. Auct. at 4.646: Dido is stated to be transgressing the rules governing the flaminica's deportment by climbing more than three steps (cf. Gellius 10.15.29);

at 7.190: Picus is said to be identified as augur by the lituus he is holding, as his ancile and trabea are shared with the flamines of Jupiter and Mars; 
Serv. Auct. at 8.363: passing reference is made to the flamen's house, the flaminia;

Serv. Auct. at 8.552: Aeneas can ride a horse (despite, the implication is, being flamen Dialis) because subordinate flamines are allowed to when on service in the provinces; at 8.664: the description of the apices of the flamines as lanigeri is explained by detailed description of the apex;

Serv. Auct. at 10.270: the apex from which flames pour on Aeneas' head is related to the flaminal apex;

Serv. Auct. at 11.76: Aeneas' actions in relation to the corpse of Pallas are claimed to reflect the taboo forbidding a flamen from touching a dead body; Serv. Auct. at 11.453: in a discussion of the name of Camilla, mention is made of the camilli and camillae who were the child attendants of the flamines and flaminicae;

Serv. Auct. at 12.120: an anecdote about a flaminica judged to have committed a piaculum by using linen when weaving a woollen garment; Serv. Auct. at 12.492: Aeneas' apex is related to the flamen's apex, as he loses it; Serv. Auct. at 12.538: flamen is cited as the title of a Roman priest; Serv. Auct. at 12.602: Amata's purple clothing is related to the flaminica's (cf. at 4.137). 